\section{International Scientific Journal Theoretical \& Applied Science}

p-ISSN: 2308-4944 (print) e-ISSN: 2409-0085 (online)

Year: $2016 \quad$ Issue: 9 Volume: 41

Published: $30.09 .2016 \quad$ http://T-Science.org

SECTION 23. Agriculture. Agronomy. Soil management. Machinery.
G. N. Churkina

candidate of biological sciences, LLP "Scientific-Production Center of Grain Farming named after A.I. Barayev", Kazakhstan

I. V. Rukavitsina

candidate of biological sciences,

LLP "Scientific-Production Center of Grain Farming named after A.I Barayev", Kazakhstan

N. I. Filippova

candidate of agricultural sciences,

LLP "Scientific-Production Center of Grain Farming named after A.I. Barayev", Kazakhstan

S. M. Dashkevich candidate of agricultural sciences, LLP "Scientific-Production Center of Grain Farming named after A.I. Barayev", Kazakhstan

G. I. Shtefan

LLP "Scientific-Production Center of Grain Farming named after A.I. Barayev", Kazakhstan gshtefan@mail.ru

D. M. Yerpasheva

LLP “Scientific-Production Center of Grain Farming named after A.I. Barayev", Kazakhstan

\title{
CREATING NEW BASELINES OF ALFALFA WITH THE GENOTYPE OF HIGH NITROGEN FIXATION
}

Abstract: This article describes a study on the development of methods of intensifying the process of symbiotic nitrogen fixation of alfalfa, by expanding the product range, introducing new varieties of legumes and creating conditions for the formation and effective functioning of their symbiosis with the relevant species of root nodule bacteria.

Key words: alfalfa, nodule bacteria, symbiotic nitrogen fixation, biological nitrogen sortomikrobnye system.

Language: Russian

Citation: Churkina GN, Rukavitsina IV, Filippova NI, Dashkevich SM, Shtefan GI, Yerpasheva DM (2016) CREATING NEW BASELINES OF ALFALFA WITH THE GENOTYPE OF HIGH NITROGEN FIXATION. ISJ Theoretical \& Applied Science, 09 (41): 71-76.

Soi: http://s-o-i.org/1.1/TAS-09-41-11 Doi: crossef http://dx.doi.org/10.15863/TAS.2016.09.41.11

\section{СОЗДАНИЕ НОВЫХ ИСХОДНЫХ ЛИНИЙ ЛЮЦЕРНЫ С ГЕНОТИПОМ ВЫСОКОЙ АЗОТФИКСАЦИИ}

Аннотация: В данной статье приведены исследования по разработке приемов интенсификации прочесса симбиотической азотфиксации люцерны, за счет расширения ассортимента, введения новых сортов бобовых культур и создания условий для формирования и эффективного функционирования их симбиоза с соответствующими видами клубеньковых бактерий.

Ключевые слова: лючерна, клубеньковые бактерии, симбиотическая азотфиксация, биологический азот, сортомикробные системы.

\section{ВВЕДЕНИЕ}

Бобовые травы в Казахстане занимают более $20 \%$ площадей пашни под производство кормовых трав. Однако в существующих сортах недостаточно реализовано одно из главных преимуществ культуры - высокая эффективность симбиотической азотфиксации $[1,2]$. Длительное время работы по изучению проблемы растительно-микробных симбиозов оставались 
монополией микробиологических институтов, создающих высокоэффективные микробные препараты. В результате роль растения-хозяина, наиболее генетически стабильного партнера растительно-микробной системы, в формировании симбиозов недооценивалась, а целенаправленная селекция бобовых на этот признак практически не проводилась[3, 4]. В этой связи исследования, направленные на разработку методов создания и получение нового исходного материала, сочетающего высокую продуктивность с повышенной способностью фиксации атмосферного азота, является актуальной задачей при создании стрессоустойчивой пермокультуры $[5,6]$.

У люцерны часть генов, детерминирующих симбиоз с клубеньковыми бактериями, участвует в контроле развития и функционирования арбускулярной эндомикоризы, а взаимодействие растений с микоризными грибами и клубеньковыми бактериями рассматривается как тройная симбиотическая система [7]. Поэтому исследования, направленные на создание высокопродуктивных ассоциаций люцерны с обоими эндо-симбионтами, являются перспективными с точки зрения повышения биологической азотфиксации и симбиотического потенциала в целом, снижения степени затратности и повышения экологической ориентированности сельского хозяйства. Создание высокоэффективных растительномикробных систем в агроценозах путем селекции сортов люцерны с высоким симбиотическим потенциалом является новаторским направлением, открывающим возможности расширения адаптивных свойств растений, придания им новых метаболических функций и на основе этого - получения высококачественной и экологически чистой сельскохозяйственной продукции $[8,9,10]$.

Методы создания высокоэффективных растительно-микробных систем в агроценозах путем селекции сортов люцерны с высоким симбиотическим потенциалом.

Свойством фиксации азота из атмосферного воздуха и синтеза органических азотсодержащих соединений обладают клубеньковые бактерии рода Rhizobium, которые образуют на корнях бобовых трав клубеньки, вступая в симбиоз. Причем разные виды бактерий развиваются на корневой системе определенных высших растений. Так у люцерны это бактерии Rhizobium meliloti. После проникновения в корневой волосок эти бактерии вызывают интенсивное деление клеток корня, в результате чего появляется клубенек. Сами бактерии развиваются в этих клубеньках на корнях, участвуя в ассимиляции азота. Там они трансформируются в разветвленные формы - бактероиды, поглощающие молекулярный азот, аммонийные соли, аминокислоты, нитраты. В качестве источника углерода клубеньковые бактерии используют моносахариды, дисахариды, спирты, органические кислоты. Если корни бобовых отмирают, а клубеньки разрушаются, клубеньковые бактерии не погибают, а ведут образ жизни сапрофитов. Для исследований в период цветения люцерны из микоризы различных сортов и сложногибридных популяций были отобраны сформированные клубеньки. С помощью микробиологических манипуляций их этих клубеньков, методом посева на агаризованную бобовую среду были выделены клубеньковые бактерии. В результате ряда пассажей, получены чистые культуры Rhizobium meliloti, которые и стали объектами исследований. Клубеньковые бактерии имеют размеры от 0,5 до 3 мкм. Они не образуют спор, подвижны, грамотрицательны. Для нормального протекания обменных процессов они нуждаются в доступе кислорода. В лабораторных условиях колонии клубеньковых бактерий хорошо растут при температуре $25^{\circ} \mathrm{C}$ на плотных средах. Они имеют характерную округлую форму, слизистой консистенции, прозрачные. Из клубеньков люцерны были выделены бактерии. Для определения родовой и видовой принадлежности была проведена молекулярно-генетическая экспертиза на основании анализа нуклеотидной последовательности $16 \mathrm{~S} \quad \mathrm{rRNA}$ гена. Всего проанализировано 20 штаммов бактерий, выделенных из клубеньков различных сортов и СГП люцерны. На рисунке 1 представлена морфология клеток бактерии, выделенных из клубеньков люцерны. 


\begin{tabular}{|c|c|c|c|c|c|c|}
\hline Impact Factor: & $\begin{array}{l}\text { ISRA (India) } \\
\text { ISI (Dubai, UAE } \\
\text { GIF (Australia) } \\
\text { JIF }\end{array}$ & $\begin{array}{l}=1.344 \\
=0.829 \\
=0.564 \\
=1.500\end{array}$ & $\begin{array}{l}\text { SIS (USA) } \\
\text { PИНЦ (Russia) } \\
\text { ESJI (KZ) } \\
\text { SJIF (Morocco) }\end{array}$ & $\begin{array}{l}=0.912 \\
=0.234 \\
=1.042 \\
=2.031\end{array}$ & $\begin{array}{l}\text { ICV (Poland) } \\
\text { PIF (India) } \\
\text { IBI (India) }\end{array}$ & $\begin{array}{l}=6.630 \\
=1.940 \\
=4.260\end{array}$ \\
\hline
\end{tabular}

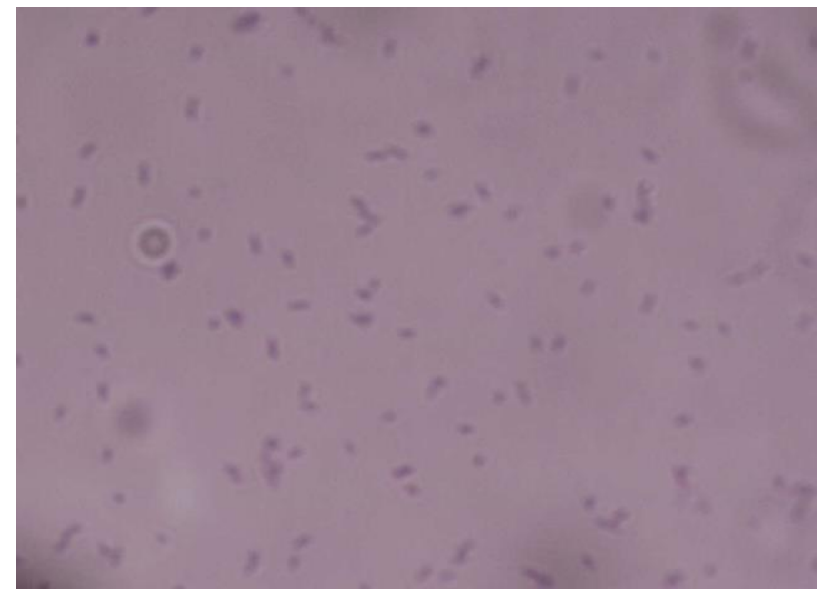

Рисунок 1 - Бактерии, выделенные из клубеньков люцерны, х1500

Идентификация осуществлена методом определения прямой нуклеотидной последовательности фрагмента $16 S r R N A$ гена, с последующим определением нуклеотидной идентичности с последовательностями, депонированными в международной базе данных GeneBank, а также построением филогенетических деревьев с нуклеотидными последовательностями референтных штаммов.

На бобовой среде была наработана биомасса ризобиальных бактерий люцерны на основе штамма В1-2013. Инокуляцию люцерны проводили перед посевом из расчета 200 мл инокулята на гектарную норму высева семян. Всего было обработано 20 образцов люцерны. Контролем служили варианты без обработки ризобиальными бактериями, также по 20 номеров каждой культуры. В период цветения люцерны был проведен отбор 10 растений с каждой делянки на контроле (без инокуляции) и с инокуляцией ризобиальными бактериями для учета клубеньков на корнях растений. Важную роль в азотфиксации играет температурный фактор и влага. В условиях 2014-2015 гг. формирование клубеньков было отмечено лишь у нескольких образцов люцерны. В первый год жизни люцерны на корнях клубеньков не образовывалось, в силу своих биологических особенностей. На корнях люцерны второго года жизни, были выделены клубеньки у люцерны изменчивой, сорт Надёжная - 9 штук, люцерны синей, сорт Canauto -16 штук, люцерны синей, сорт Радуга -18 штук, люцерны изменчивой, сорт Карабалыкская радуга - 22 штуки (табл. 1). Известно, что клубеньковые бактерии поглощают из атмосферного воздуха до 300 кг азота на 1 га, при этом в ходе их жизнедеятельности в почве остается более 50 кг азотсодержащих соединений. При оценке азотфиксирующей активности методом сравнения с не бобовой культурой, было установлено, что максимальное усвоение атмосферного азота отмечено у Люцерны синей сорта Canauto и достигало 89,2\%. У остальных образцов фиксация азота была в пределах от 83,7 до $88 \%$.

Таблица 1

Фиксация атмосферного азота растениями люцерны, инокулированной ризобиальными бактериями.

\begin{tabular}{|c|c|c|c|c|c|c|}
\hline \multirow[t]{2}{*}{ Вариант } & \multirow{2}{*}{$\begin{array}{c}\text { Количество } \\
\text { клубеньков, } \\
\text { шт. }\end{array}$} & \multirow{2}{*}{$\begin{array}{c}\text { Сухая } \\
\text { масса } \\
\text { растений, } \\
\text { г }\end{array}$} & \multirow{2}{*}{$\begin{array}{c}\text { Белок } \\
\text { растительной } \\
\text { массы, \% }\end{array}$} & \multicolumn{3}{|c|}{ Усвоено азота, мг } \\
\hline & & & & всего & $\begin{array}{c}\text { в т.ч. } \\
\text { атмосферн } \\
\text { ого }\end{array}$ & $\%$ \\
\hline Люцерна синяя сорт Canauto & 16 & 28,9 & 3,48 & 1005,7 & 897,5 & 89,2 \\
\hline Люцерна синяя, сорт Радуга & 18 & 25,2 & 3,58 & 902,2 & 794,0 & 88,0 \\
\hline $\begin{array}{l}\text { Люцерна изменчивая, сорт } \\
\text { Надёжная }\end{array}$ & 9 & 20,6 & 3,31 & 681,8 & 573,6 & 84,1 \\
\hline $\begin{array}{l}\text { Люцерна изменчивая, сорт } \\
\text { Карабалыкская радуга }\end{array}$ & 22 & 18,5 & 3,58 & 662,3 & 554,1 & 83,7 \\
\hline Житняк & & 4,6 & 2,35 & 108,1 & & \\
\hline
\end{tabular}

ISPC Global Applied Research, 
Важным фактором при активной азотфиксирующей деятельности люцерны является содержание белка в растениях. Накопление белка в растительной массе люцерны, определяли только в образцах, где было отмечено формирование клубеньков.

Результаты биохимической оценки показали, что накопление азота у четырех выделенных образцов люцерны, сформировавшей на корнях клубеньки, в растительной массе было в пределах одного порядка и варьировало от 3,31 до $3,58 \%$.

Рост и развитие растений неразрывно связаны с постоянным потреблением элементов питания. В зависимости от биологических особенностей сельскохозяйственных культур и их продуктивности, почвенного плодородия и уровня применения удобрений, климатических и погодных условий потребление питательных веществ растениями на формирование урожая может варьировать в довольно широком диапазоне.

Размер использования азота почвы растениями зависит от содержания в ней гумуса и интенсивности его минерализации, определяемой широким спектром внешних факторов. Большая часть азота почвы (97-99\%) сосредоточена органической форме, в основном в гумусе и телах микроорганизмов и недоступна для растений. По мере минерализации гумуса и растительных остатков органический азот переходит в доступные для растений минеральные соединения.

Проведенные агрохимические исследования показали, что содержание азота нитратов в почве под посевами различных сортов и СГП люцерны в период цветения колебалось в среднем от 1,72 до 6,55 мг/кг.
В посевах люцерны изменчивой Карабалыкская радуга содержание азота нитратов в почве составляло 2,28 мг/кг, что относится к низкой обеспеченности по градации О.В. Сдобниковой (табл. 2).

Почвенные пробы, отобранные в посевах люцерны изменчивой и синей, разделялись на две группы по обеспеченности почв азотом нитратов - низкой и средней (градация Сдобниковой О.В.). Высокое содержание азота нитратов в средней группе обеспеченности 6,53 и 6,55 мг/кг отмечено в образцах люцерны сорта Лазурной и образца Л-1316. Низкое содержание азота нитратов в почве отмечено в образцах Л1331, Л-1333, Л-1334 (1,74, 1,94, 1,94 мг/кг соответственно). Остальные образцы, относящиеся к низкой обеспеченности, имеют среднее содержание 3,20 мг/кг (Л-1330, Л-1332, Л-1336, Л-1326, Л-1318, Л-1323, Л-1324, Л-1341). Почвенные пробы, накопившие больше азота нитратов со средним содержанием 4,81 мг/кг, относятся к средней группе по градации. К ним относятся образцы Л-1321, Л-1317, Л-1319.

Фосфор, как и азот, играет в жизни растений важное значение, поскольку принимает непосредственное участие во всех биохимических процессах обусловливающих рост и развитие растений. К недостатку фосфора особенно чувствительны растения в первые 10-15 дней после всходов. Содержание фосфора под посевами различных сортов и сложно-гибридных популяций люцерны в период цветения находилось от очень низкого 3,8 мг/кг, до повышенного 39,4 мг/кг по шкале обеспеченности почв, включая и низкое и среднее содержание.

Таблица 2

\section{Содержание элементов питания в почве под посевами различных сортов и СГП люцерны в период цветения}

\begin{tabular}{|c|c|c|}
\hline Вариант & $\begin{array}{c}\mathrm{N}-\mathrm{NO}_{3}, \\
\mathrm{M \Gamma} / \mathrm{K} \Gamma\end{array}$ & $\begin{array}{l}\mathrm{P}_{2} \mathrm{O}_{5}, \\
\mathrm{M \Gamma} / \mathrm{\kappa} \Gamma\end{array}$ \\
\hline \multicolumn{3}{|c|}{ Люцерна изменчивая } \\
\hline Лазурная (st.) & 6,53 & 11,8 \\
\hline Л-1316 & 6,55 & 27,2 \\
\hline Л-1327 & 3,16 & 5,4 \\
\hline Л-1330 & 2,87 & 14,1 \\
\hline Л-1331 & 1,72 & 28,8 \\
\hline Л-1332 & 2,17 & 23,4 \\
\hline Л-1333 & 1,94 & 17,7 \\
\hline Л-1336 & 3,73 & 9,7 \\
\hline Л-1321, сорт Надежная & 5,49 & 34,8 \\
\hline Л-1326, сорт Семиреченская местная & 3,96 & 34,4 \\
\hline
\end{tabular}




\section{Impact Factor:}

\begin{tabular}{|c|c|c|}
\hline ISRA (India) & $=1.344$ & SIS (USA) \\
\hline ISI (Dubai, UAE & $=0.829$ & РИНЦ $($ Russia $)=\mathbf{0 . 2 3 4}$ \\
\hline IF (Australia) & $=0.564$ & ESJI $(\mathrm{KZ}) \quad=\mathbf{1 . 0 4 2}$ \\
\hline & $=1.500$ & SJIF $($ Morocco $)=\mathbf{2 . 0}$ \\
\hline
\end{tabular}

\begin{tabular}{|l|r|c|}
\hline Л-1329 & 2,26 & 16,3 \\
\hline Карабалыкская радуга (st) & 2,28 & 28,4 \\
\hline Л-1334 & 1,94 & 18,9 \\
\hline Л-1317, сорт Карабалыкская жемчужина & 4,23 & 39,4 \\
\hline \multicolumn{3}{|c|}{ Лючерна синяя } \\
\hline Л-1318 Conanto & 3,80 & 22,4 \\
\hline Л-1319 Радуга & 4,72 & 15,9 \\
\hline Л-1323 Планет & 2,71 & 3,8 \\
\hline Л-1324 Кевсала & 3,98 & 10,3 \\
\hline Л-1341 Уральская синяя & 3,32 & 19,6 \\
\hline
\end{tabular}

В почвенных образцах Л-1317, Л-1321, Л1326 наблюдалась тенденция увеличения фосфора, которая составляла 39,4, 34,8, 34,4 мг/кг соответственно. Заметное снижение фосфора в почве происходило у образцов Л-1323, Л-1336, Л1327 и составляло в среднем 6,3 мг/кг. На остальных образцах содержание фосфора находилось на среднем уровне согласно шкалы обеспеченности, и было в пределах от 15,9 до 28,8 мг/кг. Интенсификация процесса симбиотической азотфиксации у люцерны влияет и на продуктивность культуры. Проведенные исследования показали, что при инокуляции семян люцерны и донника отмечалась прибавка урожая сухого вещества и семян в сравнение с контролем (табл.3).

\section{Урожайность сухого вещества и семян различных сортов люцерны}

Таблица 3

\begin{tabular}{|l|c|c|c|c|}
\hline \multicolumn{1}{|c|}{ Варианты } & \multicolumn{3}{|c|}{ Урожайность, ц/га } \\
\cline { 2 - 5 } & $\begin{array}{c}\text { сухого } \\
\text { вещества }\end{array}$ & прибавка & семян & прибавка \\
\hline Люцерна синяя сорт, Сапаито (без инокуляции) & 62,4 & & 1,9 & \\
\hline $\begin{array}{l}\text { Люцерна синяя, сорт Сапаuto (инокуляция } \\
\text { ризобиальными бактериями) }\end{array}$ & 67,4 & +5 & 2,1 & $+0,1$ \\
\hline Люцерна синяя, сорт Радуга (без инокуляции) & 67,9 & & 2,0 & \\
\hline $\begin{array}{l}\text { Люцерна синяя, сорт Радуга (инокуляция ризобиальными } \\
\text { бактериями) }\end{array}$ & 72,7 & $+4,8$ & 2,1 & $+0,1$ \\
\hline Люцерна изменчивая, сорт Надёжная (без инокуляции) & 66,4 & & 2,1 & \\
\hline $\begin{array}{l}\text { Люцерна изменчивая, сорт Надёжная (инокуляция } \\
\text { ризобиальными бактериями) }\end{array}$ & 70,4 & +4 & 2,2 & $+0,1$ \\
\hline $\begin{array}{l}\text { Люцерна изменчивая, сорт Карабалыкская радуга } \\
\text { (без инокуляции) }\end{array}$ & 63,8 & & 2,2 & \\
\hline $\begin{array}{l}\text { Люцерна изменчивая, сорт Карабалыкская радуга } \\
\text { инокуляция ризобиальными бактериями) }\end{array}$ & 70,2 & $+6,4$ & 2,4 & $+0,2$ \\
\hline
\end{tabular}

В целом, урожайность сухого вещества люцерны на всех вариантах с инокуляцией колебалась в среднем от 54,6 до 68,4 ц/га, на контроле от 50,4 до 62,5 ц/га. Урожайность семян люцерны с инокуляцией варьировала от 1,8 до 2,3 ц/га, без инокуляции от 1,6 до 2,1 ц/га.

В частности, среди изучаемых сортов и СГП люцерны по урожайности сухого вещества и семян выделились 4 образца (табл. 2).
Как видно из таблицы 3 наибольшая прибавка (+6,3 ц/га) по урожаю сухого вещества среди представленных образцов была у люцерны изменчивой сорта Карабалыкская радуга, инокулированной ризобиальными бактериями и составляла 70,2 ц/га. Наименьшая (+4 ц/га) у люцерны изменчивой, сорта Надёжная (инокуляция ризобиальными бактериями). 


\section{ЗАКЛЮЧЕНИЕ}

Таким образом, в результате идентификации 20 штаммов бактерий, выделенных из клубеньков люцерны методом анализа фрагмента 16SrRNA гена, была получена молекулярно-биологическая характеристика штамма.

При оценке азотфиксирующей активности методом сравнения с не бобовой культурой, было установлено, что максимальное усвоение атмосферного азота было отмечено у образца люцерны синей Л-1318 и достигало 89,2\%. У остальных образцов фиксация азота варьировала в пределах от 83,7 до $88 \%$.

В результате исследований было установлено, что содержание азота нитратов в почве под посевами различных сортов и СГП люцерны в период цветения колебалось в среднем от 1,72 до 6,55 мг/кг, и в целом, все образцы по градации О.В. Сдобниковой можно было отнести к низкой и средней обеспеченности. Высокое содержание азота нитратов в средней группе обеспеченности $(6,53$ и 6,55 мг/кг почвы) отмечалось в посевах люцерны сорта Лазурной и образца Л-1316.
Низкое содержание азота нитратов в почве отмечено в посевах образцов Л-1331, Л-1333, Л1334 (1,74, 1,94, 1,94 мг/кг соответственно). Остальные образцы, относящиеся к низкой обеспеченности, имели среднее содержание 3,20 мг/кг.

Заметное снижение фосфора в почве под посевами различных сортов и СГП люцерны наблюдалось у образцов Л-1323, Л-1336, Л-1327 и составляло в среднем 6,3 мг/кг. На остальных образцах содержание фосфора находилось на среднем уровне согласно шкалы обеспеченности, и было в пределах от 15,9 до 28,8 мг/кг.

Инокуляция семян люцерны ризобиальными бактериями, в большей степени оказала влияние на урожайность сухого вещества, нежели семян. Из всех изучаемых сортов и сложно-гибридных популяций люцерны, следует выделить образцы, инокулированные ризобиальными бактериями, которые дали прибавку урожая сухой массы - это люцерна синяя образец Л-1318 и Л-1319 и люцерна изменчивая образец Л-1321 и Л-1316.

\section{References:}

1. Buyankin NI (2005) Biologizatsiya zemledeliya i rastenievodstva - perspektivnoe napravlenie // Vestnik RASKhN - 2005. №2. - pp. 40-42.

2. Tikhonovich IA, Provorov NA (2009) Simbioz rasteniy i mikroorganizmov: molekulyarnaya genetika agrosistem budushchego//Izd-vo S.Peterb. un-ta, 2009. - 210 p.

3. Drobysheva LV, Zyatchina P (2013) Sozdanie iskhodnogo selektsionnogo materiala razlichnykh vidov kleverov $\mathrm{s}$ povyshennoy biologicheskoy azotfiksatsiey //Sb. tr. Mezhd. nauchn.-prakt. konf. «Mnogofunktsional'noe adaptivnoe kormoproizvodstvo», posvyashchennoy pamyati akademika Rossel'khozakademii B. P. Mikhaylichenko. Moscow. 2013. - pp.178- 184 .

4. Tikhonovich IA (2000) Sozdanie vysokoeffektivnykh mikrorastitel'nykh sistem// S.-kh. biologiya.- 2000. - №1.- pp.28-33.

5. Zadorin AD (2003) Novaya tekhnologiya polucheniya belkovo-uglevodnykh produktov iz zerna bobovykh kul'tur // Kormoproizvodstvo. - 2003. - N10.-pp.30-32.

6. Borisov AY, Vasil'chikov AG, Voroshilova VA, et al. (2007) Regulyatornye geny gorokha posevnogo (Pisum sativum L.), kontroliruyushchie razvitie azotfiksiruyushchikh kluben'kov i arbuskulyarnoy mikorizy: fundamental'nye i prikladnye aspekty // Prikladnaya biokhimiya i mikrobiologiya. T. 43. № 3. - 2007.- pp. 265271.

7. Tikhonovich IA, Provorov NA (2005) Printsipy selektsii rasteniy na vzaimodeystvie $\mathrm{s}$ simbioticheskimi mikroorganizmami //Vestnik VOGiS.- 2005.- T.9. - №3.- pp. 295-305.

8. Tepper EZ, Shil'nikova VK, Pereverzeva GI (2005) Praktikum po mikrobiologii. - Moscow. 2005.-256 p.

9. Buchkina NP, Balashev EV, Rizhiya EY, Pavlik SV (2008) Monitoring emissii zakisi azota iz sel'skokhozyaystvennykh pochv. - S.Peterb. 2008.-pp.15-16.

10. Kumar S, Tamura K, Nei M (2004) MEGA3: Integrated software for Molecular Evolutionary Genetics Analysis and sequence alignment // Briefings in bioinformatics. - 2004. - Vol. 5, №2. - pp. 150-163. 